\title{
Mediatization in the Arab World: A Cross-Cultural Comparison of New Media Use
}

\section{Julie B. Wiest, West Chester University of Pennsylvania, USA Nahed Eltantawy, High Point University, USA}

\begin{abstract}
New media (including online and cellular technologies) are being embraced around the world, and younger people have led the way in their adoption. These technologies have spread particularly quickly in the Middle East as a result of innovations in satellite, cellular, and Internet technology. In addition, the Arab Spring was a major milestone for new media adoption in the Middle East and helped define appropriate uses for these technologies. Although they have been used for activism and expression, evidence suggests that these are not (or perhaps are no longer) the primary uses of these technologies among young Arabs. Drawing on the concept of mediatization in an analysis of surveys of American and Arab young people, this study explores cultural influences in recent online and cellular technology use in the Arab world, as well as cultural consequences of the increasing adoption of these technologies. In particular, it identifies and explores similarities and differences among the two groups regarding ownership of devices, online and cellular activities, and frequency of these activities. Findings reiterate the prominence of new media in the Arab world and suggest a continuing influence of traditional values, as well as an increasing influence of Western culture.
\end{abstract}

Keywords: cell phones, Internet, mediatization, new media, United Arab Emirates, United States 
New media (including online and cellular technologies) have become ubiquitous in much of the world. Looking first at the United States, about 85 percent of Americans ${ }^{1}$ are Internet users, and nearly all (96 percent) Americans ages 18-29 use the Internet (Rainie, 2012). About 88 percent of U.S. adults own a cell phone, and those ages 18-29 are the most likely to use their cell phone to access the Internet as well as the most likely to own a smart phone (Zickuhr \& Smith, 2012). When it comes to social media, about 69 percent of U.S. Internet users use those services, including about 92 percent of 18- to 29-year-olds (Rainie, Smith, Schlozman, Brady, \& Verba, 2012).

Other Western nations appear to have similar levels of new media adoption. The Pew Research Center (2011) examined digital communication within 21 nations, finding similar levels of Internet, cell phone, and social media use in the five Western nations that were included in the study (Britain, France, Germany, Spain, and the United States). In nonWestern countries, cell phone ownership is particularly widespread: Of the 16 non-Western nations surveyed by the Pew Research Center (2011), approximately half or more of those populations use cell phones (from 48 percent in Pakistan to 95 percent in Jordan and Israel). But social media use varies more in non-Western nations. More than half of Israel's population use social media services, for example, compared to about half in Russia, onethird in China, one-quarter in Japan, and less than one-tenth in India (Pew Research Center, 2011). In nearly every country around the world, however, young people are more likely than middle-aged and older people to use online and cellular technologies (Pew Research Center, 2011).

The Arab world, in particular, has embraced new media. Although government control and censorship of traditional forms of mass media continue in the Middle East, innovations in satellite, cellular, and Internet technology are helping unlock the media environment. The number of Internet users in the region has grown rapidly, especially during and since the Arab Spring, and is expected to reach 100 million by 2015 (Ghannam, 2011). Despite this, there is national variation in Internet adoption, with about half of those in Israel using the Internet, one-quarter in Jordan, and even fewer in Lebanon and Egypt (Pew Research Center,

\footnotetext{
${ }^{1}$ American is used throughout to refer to residents of the United States of America.
} 
2011). Although it is one of the smallest Middle Eastern nations in terms of population (Central Intelligence Agency, 2012), the United Arab Emirates (UAE) is an Internet adoption leader in the Arab world, with about 70 percent of its population online (World Bank, 2011). Cell phone ownership also has increased in the Middle East, with the majority in several countries (e.g., Jordan, Lebanon, and Egypt) reporting that they own a cell phone and regularly use it to make phone calls and send text messages (Pew Research Center, 2011). With increasing access to Internet and cell phones, a growing number of Middle East residents use social media services (Pew Research Center, 2011; Salem \& Mourtada, 2012). Facebook is the most popular social media service in the Arab world, with about 45.2 million users (about 12 percent of the region's population), which is almost triple the 16 million Arab users in 2010 (Salem \& Mourtada, 2012). Twitter also is rapidly gaining in popularity, with nearly 2.1 million users (Salem \& Mourtada, 2012). When considering population size, the United Arab Emirates leads the Arab region in Facebook users, while Turkey leads for Twitter (Salem \& Mourtada, 2012).

It is clear that new media are being embraced in many nations around the world and that younger people have led the way in the adoption of online and cellular technologies. Of interest here is the rapid spread of new media within the Arab world and the potential social and cultural implications. Comparing online and cellular technology use in the United Arab Emirates and the United States will not only contribute to knowledge in this area, but it also may suggest evidence of social and cultural change within the Arab world. Findings also could have important implications for other non-Western cultures.

\section{Literature Review}

\section{New Media in the Arab World}

Online and cellular technologies have provided new opportunities for information sharing, personal expression, social networking, and activism, especially in regions like the Middle East, where these activities traditionally have been limited in the public sphere (Al-Jenaibi, 2011). Even before the Arab Spring, scholars suggested the important role these technologies were playing for social and cultural change. Al-Saggaf (2006) explored the potential for online technologies to foster civic engagement in the Arab world by examining readers' comments on a popular television station website. Studying Internet use in Palestine, Aouragh (2008) suggested that the technology has altered the tactics of activists and 
strengthened social and political agency among citizens. Mohamed (2011) explored the ways in which Egyptian bloggers helped transform traditional journalism, enhance activism, and expand the public sphere. Finally, several scholars have studied the ways in which Arab women use blogs (Elsadda, 2010; Monteiro, 2008) and email (Al-Hail, 2005) to challenge prevailing socio-cultural norms in the region.

The use of these technologies for social and political activism has been the subject of many studies since the Arab Spring, when their use increased dramatically in the region, with most concluding that they were an integral force in launching and sustaining the revolutions (e.g., Al-Jenaibi, 2011; Al-Momani, 2011; Alqudsi-ghabra, 2012; Eltantawy\&Wiest, 2011; Iskander, 2011; Russell, 2011; Salem \& Mourtada, 2012; Wall \& El Zahed, 2011; Weber, 2011). The impact was not just felt in Tunisia, Egypt, and Libya: After examining new media trends in 22 Arab countries immediately after the Arab Spring, Mourtada and Salem (2011) concluded that new media played a vital role in "mobilization, empowerment, shaping opinions, and influencing change” (p. 24) in the region and would continue to play a powerful role in political and economic developments there.

Despite the evidence that Arabs, particularly younger residents, used new media for activism and expression before, during, and after the Arab Spring, other studies have found that these generally are not their primary uses of these technologies, especially recently. An analysis of new media use among UAE college students one year after the Arab Spring (Wiest \& Eltantawy, 2012) indicates that this group mostly uses the Internet and cell phones for social purposes and that interest in using new media for activism or for gaining or sharing political knowledge is extremely low. Another study of UAE college students (Ayyad, 2011) found that their primary reasons for accessing the Internet were for social and entertainment purposes and to locate information for their studies or about current events. Also studying UAE college students, Sokol and Sisler (2010) found privacy concerns regarding Internet use, despite their widespread use of online technologies, and these concerns tended to be highest among those most lacking in social power. Studying Arab Americans, Muhtaseb and Frey (2008) found that information-seeking was the most salient motive for using the Internet. 


\section{Cultural Influences in New Media Use}

Although no studies were found that compare new media use between Americans and Arabs, a number of studies examined cultural influences in the ownership and uses of online and cellular technologies. Shuter and Chattopadhyay (2010) found cultural differences in text messaging norms - or what they call "textiquette" - between Americans and Indians. Indian participants preferred to send and read received text messages in private settings and while in the company of significant others (i.e., family members or a romantic partner), while American participants preferred to text in public settings and while in the presence of insignificant others (i.e., strangers/acquaintances or friends) (Shuter \& Chattopadhyay, 2010). Sreekumar's (2011) study also found that cell phones were mostly used as a means for collective communication among fishers in Kerula, India. Campbell (2007a) found more tolerance of cell phone use in public among American and Swedish participants compared to participants from Japan. In a different study, Campbell (2007b) found that Japanese participants were tolerant of cell phone use in a classroom but not on a sidewalk or bus, while Taiwanese participants were tolerant of cell phone use in a theater, restaurant, and classroom.

Leonardi (2003) found that U.S. Latinos drew on cultural values regarding good communication to evaluate the usefulness of cell phones, computers, and the Internet. In general, participants indicated that cell phones can facilitate the kind of contact that is necessary for good social relations, while they found the impersonal nature of computers and the Internet to be damaging to interpersonal communication (Leonardi, 2003). In his study of cell phone use among young Latinos in Argentina, Chile, Colombia, Mexico, the United States, and Uruguay, Albarran (2009) found that only the U.S. participants preferred using cell phones to share social information with friends, while participants in the other five countries preferred face-to-face communication.

Barray and Bouvier (2011) found differences in Welsh and UAE students' use of Facebook, which they attribute to a cultural dissimilarity in communication preferences. The Arab students indicated a preference for using Facebook as a means for collective communication (e.g., they preferred to post messages on "walls," rather than send individual messages) or to reach out to the world, while the Welsh students tended to view Facebook as an extension of their offline social life and used it to maintain personal relationships (Barray \& Bouvier, 2011). Similarly, Vasalou, Joinson, and Courvoisier (2010) found differences in motivations 
for using Facebook and time spent with the service among participants from the United States, the United Kingdom, Italy, and France. And Barker and Ota (2011) found cultural influences in social networking service use among Japanese and American young women: The Japanese women were more likely to restrict their communication to a select group of friends and preferred more privacy and closeness in their correspondence compared to the American women.

Several scholars have suggested that new media can lead to cultural and social change. Wasserman (2011), for example, theorized about the possibilities presented by cellular technologies for encouraging political participation and democratic debate within Africa. Harp, Bachmann, and Guo (2012) explored the ways in which activists in China, Latin America, and the United States use new media for mobilization. Lin and Tong (2007) examined texting among young people in Hong Kong, concluding that the cellular technology is contributing to gradual change in the traditional gendered communication patterns among that group. Specifically, the scholars found that, via text, young men were more willing to express their emotions and inner thoughts with their friends and that young women were more willing to take on active and expressive social roles, especially those involving activities more traditionally associated with men, such as initiating a romantic relationship (Lin \& Tong, 2007).

In sum, a number of scholars have explored the role of culture in uses of and attitudes about online and cellular technologies, as well as the role of these technologies in facilitating cultural and social change. Of particular interest in this study, several scholars have examined the role of these technologies in the Arab world, especially as they helped sustain the Arab Spring revolutions, yet few have examined uses of these technologies in the contemporary Arab world or factors affecting observed patterns of use. This study, guided by the theoretical framework explained next, helps fill that gap.

\section{“Mediatization” of Culture and Society}

Although the concept of mediatization has been used in various contexts to characterize media influence (e.g., Schulz, 2004; Thompson, 1995), Hjarvard (2008) proposed a clearer conceptualization that may be used as a theory of media influence on culture and society. Hjarvard (2008) explained his concept of mediatization as a process of highly modern 
societies such that mass media can no longer be conceived as separate from cultural and social institutions. To say that society and culture have become mediatized is to say that "social and cultural institutions and modes of interactions are changed as a consequence of the growth of the media's influence” (Hjarvard, 2008, p. 114). The process is twofold: Media have both "become integrated into the operations of other social institutions" while also having "acquired the status of social institutions in their own right" (emphasis is original) (Hjarvard, 2008, p. 113). Hjarvard (2008) suggested that one consequence of mediatization is that social interactions begin to take place via the media.

Because it is linked to modernity, mediatization is primarily a development of highly industrialized - and mostly Western - nations during the latter years of the 20th century (Hjarvard, 2008). However, mediatization is affecting more and more nations as globalization progresses (Hjarvard, 2008). Chen (2012) examined the rapid development of new media around the world and argued that the speed at which online and cellular technologies have spread has "resulted in the inability of traditional values to keep pace with the new cultural values produced by new media” (p. 4). Singh (2010) agreed, arguing that the "threads which bind the cultural identities are being replaced with new, alien, textured, colorful, attractive but weak threads of new media” (p. 89). This suggests that Western culture - spread through new media - is being integrated into non-Western cultures more quickly and with less resistance than in the past. This may be especially true for younger generations (Singh, 2010).

There is evidence that these technologies have accelerated the dissemination of a heavily Western dominant global culture in the Arab world. One example of this is the continued use of Western languages in text messages and Twitter messages despite the introduction of the Arabic keyboard in 2000. Salem and Mourtada (2012) found that Arabic is the preferred language of Facebook users in seven Arab countries - Yemen, Palestine, Libya, Iraq, Egypt, Saudi Arabia, and Jordan - but English is still the preference for about 20 percent to 45 percent of users in those countries. English is preferred by majorities in Oman, Bahrain, Kuwait, Qatar, the United Arab Emirates, Lebanon, and Somalia, and French is preferred by majorities in Mauritania, Algeria, Morocco, Tunisia, and Comoros (Salem \& Mourtada, 2012). Haggan (2007) found that most text messages sent in Kuwait are either typed in English only or some combination or English and Arabic, with only 27.4 percent of messages sent in Arabic only. In addition, Daoudi (2011) suggests that globalization has led to the development of an “e-Arabic," or an adaptation of the Arabic language specifically for new 
media that borrows from Western languages and incorporates Western online communication styles, including the use of emoticons.

\section{Methodology}

\section{Research Questions}

Based on the studies and concepts just reviewed, we seek to explore cultural influences and implications in the adoption of new media by examining similarities and differences between young Arabs and young Americans in their uses of online and cellular technologies. Therefore, we pose the following research questions:

RQ1: Is there a relationship between online and cellular device ownership and nationality?

RQ2: Is there a relationship between online and cellular activities and nationality?

RQ3: Does the frequency of online and cellular activities vary by nationality?

\section{Data Collection}

To compare the uses of online and cellular technologies among young Arabs and young Americans, we compiled a unique dataset using data from two separate surveys asking about uses of and attitudes about online and cellular technologies. The first survey was designed and administered over the phone from June 26 to September 24, 2009, by researchers with the Pew Research Center's Internet \& American Life Project (see Lenhart, Purcell, Smith, \&Zickuhr, 2010). The researchers composed a representative sample of 800 teenagers living in the continental United States. The full survey and SPSS dataset are accessible via the Pew website.

We designed the second survey using many of the same questions asked on the Pew survey so that we would be able to easily compare results. Our survey was administered online from February 28 to April 28, 2012, and completed by 179 undergraduate students at four universities in the United Arab Emirates: University of Sharjah (private), American University of Sharjah (private), Zayed University (private), and United Arab Emirates University (public). (Recruiting participants mostly within private institutions helped to draw a more representative sample of Arab young adults, as public universities in the United Arab Emirates only admit UAE nationals.) We gained access to the students through university instructors with whom we had established contact. The United Arab Emirates was selected as an ideal site for accessing young Arabs for three major reasons. First, although most of its 
residents are Arab and Muslim, it also has a diverse population in terms of nationality and includes many Arabs and Muslims from neighboring countries (U.S. Department of State, 2011). Second, the United Arab Emirates is more balanced than most other Arab countries in terms of the ages and gender of new media adopters (Salem \& Mourtada, 2012). Third, a large majority (about 90 percent) of online and cellular technology users in the United Arab Emirates prefer to use English in their communications (Salem \&, Mourtada 2012), which helped ensure that respondents would feel confident and comfortable with our Englishlanguage survey.

\section{Sample}

The final sample includes 979 teenagers and young adults: 800 American and 179 Arab. The American sample includes more male respondents than female (53.6\% male), and the Arab sample is heavily female (73.3\% female), making the combined sample nearly even (51.1\% female). The apparent gender imbalance of the Arab sample is consistent with the population of college students within the United Arab Emirates (Abdulla \& Ridge, 2011), though inconsistent with the largely male composition of the United Arab Emirates and most of the Arab world (Telhami, 2003). Although the American sample includes respondents ages 12-17 and the Arab sample includes respondents ages 18-26, the samples are more comparable than it may appear. First, the American sample skews older (i.e., most of the respondents are 1517 years old), and the Arab sample skews younger (i.e., most of the respondents are 18-22 years old). Further, Lenhart et al. (2010) found that American teens and young adults use online and cellular technologies in extremely similar ways, except when it comes to Twitter, which American young adults are more likely to use than American teens.

\section{Analysis}

The final dataset is composed only of variables that were included in both separate surveys, and each variable was tested separately. In total, there was one independent variable (the grouping variable nationality - either Arab or American); 30 dependent variables (five addressing device ownership, 16 addressing online activities, and nine addressing frequency of online activities); and two control variables (gender and age). Therefore, each of the three research questions contained multiple hypotheses for testing (see Table 1). We were interested in relationships between the independent and dependent variables, but because the sample sizes are uneven and the Arab sample is not normally distributed, we used 
nonparametric statistics for analysis. (The one-sample Kolmogorov-Smirnov test revealed that none of the variables from the Arab sample is normally distributed. However, this may indicate unusual population characteristics, as the data appear comparable to national composition data and data described in related literature.) For variables measured at least at the ordinal level, the Mann-Whitney test was used to investigate differences in responses between the Arab and American samples. For variables measured at the nominal level, chisquare tests were performed. Results are compiled in Table 1.

\section{Results}

Significant differences were found between the samples for nearly all dependent variables. For Research Question 1, four of the five testing hypotheses were supported. There were significant relationships between the samples regarding ownership of cell phones, personal computers, game consoles, and portable gaming devices, but not for MP3 players. Nearly all Arab respondents reported owning a computer (99.4\%) and a cell phone (98.3\%), while $68.5 \%$ of the American sample reported owning a computer and $78.1 \%$ a cell phone. In contrast, the American respondents were more likely to own game systems: $80.5 \%$ reported owning a game console (compared to 53.5\% of Arab respondents) and 51\% reported owning a portable game console (compared to $34.3 \%$ of Arab respondents). The two groups were close on MP3 player ownership, with $81.3 \%$ of the American sample and $75.6 \%$ of the Arab sample owning the devices.

For Research Question 2, 15 of the 16 testing hypotheses were supported. More Arab respondents reported using the Internet (99.4\% compared to 91.6\%), email (99.4\% compared to $69 \%$ ), social networking services (87.4\% compared to $74 \%$ ), and Twitter (70.1\% compared to $8.2 \%$ ); visiting virtual worlds (15.2\% compared to $8.2 \%$ ); creating or working on an online journal or blog (43\% compared to $13.2 \%$ ); remixing online material into an original work (59.3\% compared to $20 \%$ ); sharing an original work online (70.9\% compared to $40.1 \%$ ); searching online for uncomfortable health information (72.6\% compared to $16.6 \%$ ); searching online for health, dieting, or fitness information (85.1\% compared to 30.2\%); searching online for information about current events or politics (81.4\% compared to 63.8\%); and using the Internet on a personal computer (99.4\% compared to 93.4\%), personal game console (34.6\% compared to $24.7 \%$ ), personal portable gaming device (39.4\% compared to $19.4 \%$ ), and personal cell phone (92.6\% compared to 26.9\%). The only area in which no 
significant difference was found was in online purchasing, with similar percentages of both groups reporting purchasing items online $(54.1 \%$ of the Arab sample and $49.3 \%$ of the American sample).

For Research Question 3, eight of the nine testing hypotheses were supported. Nearly all of the Arab respondents reported using the Internet at least daily, with 92\% reporting use several times a day (compared to 37.1\% of American respondents) and another 5.7\% reporting use about once a day (compared to $27.3 \%$ of American respondents). In all other areas, however, the American respondents reported more frequent use than the Arab respondents, including frequency of posting comments to a friend's blog (53.5\% reported “every day," compared to $12 \%$ of the Arab sample); frequency of adding comments to a friend's picture (82.6\% reported "every day," compared to $16.6 \%$ of the Arab sample); frequency of posting comments to a friend's page or wall (86.6\% reported "every day," compared to $24.7 \%$ of the Arab sample); frequency of joining groups on a social networking service (42.3\% reported “every day," compared to $19.6 \%$ of the Arab sample); frequency of sending a bulletin or group message to a group of friends (50\% reported "every day," compared to $17.1 \%$ of the Arab sample); frequency of sending instant messages or text messages to a friend through social networking services (58.6\% reported "every day," compared to $36.1 \%$ of the Arab sample); and frequency of sending private messages to a friend within social networking services (70.1\% reported “every day,” compared to $23.8 \%$ of the Arab sample). The only area in which no significant difference was found was in the frequency of cell phone use to browse or update social networking profiles: Most of the Arab respondents and all of the American respondents reported doing this every day or several times per week.

\section{Discussion}

These results suggest similarities between young Arabs and young Americans regarding uses of online and cellular technologies, as well as important differences. Caution should be used in evaluating some of these results, however, as some of the significant relationships found may be at least partly attributed to differences between the samples. For example, age differences between the two groups likely explain differences in computer and cell phone ownership. In addition, group differences at least partly explain the enormous difference observed in Twitter use $\mathbf{7 0 . 1 \%}$ of the Arab sample reported using the service, compared to just $8.2 \%$ of the American sample). As mentioned previously, Twitter use is one area in 
which American teens and young adults differ, with American teens less likely than American young adults to use the service (Lenhart et al., 2010). Lenhart et al. (2010) found that about one-third of American young adults use Twitter, which is perhaps a better comparison for our Arab sample, albeit still representing a large difference in use between the groups. Findings from other studies (e.g., Salem \& Mourtada, 2012) suggest that new media adoption during the Arab Spring may have fueled an enormous growth in Twitter use in the region.

Four findings should be emphasized because of their unique contributions to the literature. First, the study results indicate that young Arabs and Americans are participating in similar online and cellular activities, but Americans' participation is more frequent, especially when it comes to activities that are primarily social in nature. The Arab participants also engage in social activities online (commenting on a friend's blog, photograph, page or wall; joining groups on a social networking service; sending group or personal messages via a social networking service; and using cell phones to browse or update social networking profiles), but not as frequently as the American participants. The Arab participants, however, reported more frequent Internet use overall.

Second, although the Arab participants used online and cellular technologies for social purposes, they appear less likely than the American participants to use them for private or personal connections. This is consistent with findings from previous studies of online and cellular communication patterns of more collectivistic cultures (Albarran, 2009; Barray \& Bouvier, 2011; Leonardi, 2003). In general, the Arab participants preferred to use the Internet and cell phones mostly for information-seeking, which is also consistent with previous studies (Ayyad, 2011; Muhtaseb \& Frey, 2008). This may indicate discomfort with private or personal communication because of cultural taboos or privacy concerns (Sokol \& Sisler, 2010). It also may indicate fear of the consequences of such communication in a region with a long history of government control and censorship of expression. Despite recent changes, the United Arab Emirates has among the lowest levels of Internet freedom in the Middle East (Salem \& Mourtada, 2011).

Third, in addition to using the Internet for information-seeking more than American participants, the Arab participants were searching for particular kinds of information online: 
mostly information about current events or politics, as well as health, dieting, and fitness topics. The prevalence of online news-seeking among this group may indicate a continued mistrust of public sources of information and local media in the Arab world. Despite some unlocking of the media environment in the Middle East, the UAE government maintains a high level of control over the local press, and many journalists also practice self-censorship (El-Baltaji, 2009; Human Rights Watch, 2011). The prevalence of searching for information on health topics likely reflects the female-heavy gender composition of the Arab sample, as well as contemporary social problems in the Gulf region such as increasing rates of obesity and related health problems like cardiovascular diseases, diabetes, and cancer (Moosa, 2002; Ng et al., 2011).

Fourth, the Arab participants appear to be much more involved in creative activities online, especially creating or working on an online journal or blog, remixing online material into an original work, and sharing an original work online. This finding likely can be explained by a variety of factors in the region, including the growth of Internet access and a general lack of outlets for personal expression offline. In addition, online piracy is common in the region, partly due to a lack of awareness of copyright laws, as well as difficulties in their enforcement (e.g., Al Qasimi, 2011; Al-Rafee \& Rouibah, 2010).

\section{Conclusions}

There is clear evidence of mediatization in the Arab world. New media have been embraced by large proportions of the population and have become integrated into public and private life. Social interactions regularly take place via these technologies, and the technologies serve as primary agents of socialization and cultural dissemination. There also is strong evidence of cultural influences in the attitudes toward and uses of these technologies. Much of this influence appears to be traditional, in that young Arabs' uses of the technologies still conform in some ways to traditional values and longstanding social constraints. However, there is evidence of change. The media environment is opening up somewhat in the Arab world, with increased opportunities for information sharing, self-expression, and the formation of social relationships, and this is reflected in the Arab participants' uses of and attitudes about these technologies. At the same time, this changing environment also encourages increased exposure to other cultures. Similarities found between the young Arabs and young Americans in this study suggest a growing adoption of a global - and primarily Western - culture. 


\section{Limitations and Suggestions for Future Research}

There are several important limitations to this study that should be considered in evaluating these findings and embarking on future research in this area. We urge further research to address these limitations and contribute to better understanding of the influence of the cultural, historical, and social contexts in the ways different groups use online and cellular technologies. Expanding knowledge in this area will contribute to understanding the impacts of new media, mass media, and globalized culture. Based on study limitations, we have four specific suggestions for future research.

First, this study should be replicated with data drawn from more recent timeframes. The Pew data is the most recent available that provides a comparable American sample for our Arab sample, yet those data were collected nearly three years before the Arab data were collected. More recent U.S. studies indicate that there is likely little difference between American young adults and teens from 2009 to 2012 in their uses of and attitudes about online and cellular technologies (e.g., Lenhart, 2012; Smith, 2011; Smith \& Brenner, 2012), but further research is needed.

Second, it would be useful to conduct a similar study using data drawn from the Egyptian population. Egypt's revolution was part of the Arab Spring, and Egyptians lead the Arab world in use of new media for activism (Ghannam, 2011). It would be interesting to compare young people's new media use there with use in the United Arab Emirates and the United States.

Third, future research should incorporate additional variables for analysis. For example, in their study of youth in Brussels, Mertens and d'Haenens (2010) found an important influence of socioeconomic status and ethnicity in participants' access to digital technologies. Our sample (college students in the oil-rich United Arab Emirates) was likely too homogeneous on these variables for these data to be meaningful, but scholars conducting future studies should be mindful of these potential influences.

Finally, the American and Arab samples in this study are uneven. Not only are the sample sizes different, but the American sample was randomly selected and is representative of its population while the Arab sample was not randomly selected and is not representative of the 
population of Arab young adults or even the population of UAE undergraduate students. The use of nonparametric statistics helps account for these issues, but they nevertheless should be noted in evaluating the results. 


\section{References}

Abdulla, F., \& Ridge, N. (2011). Where are all the men? Gender, participation and higher education in the United Arab Emirates.Dubai School of Government Working Paper Series, 11-03: 1-15. Accessed June 26, 2012, at http://www.dsg.fohmics.net/en/ Publication/Pdf_Ar/WP11-03.pdf.

Albarran, A. B. (2009). Young Latinos’ use of mobile phones: A cross-cultural study. Revista de Communicacion, 8, 95-108.

Al-Hail, A. (2005). Why women use email disproportionately in Qatar: An exploratory study. Journal of Website Promotion, 1(3), 99-104.

Al-Jenaibi, B. (2011). The use of social media in the United Arab Emirates - An initial study.European Journal of Social Sciences, 23(1), 84-97.

Al-Momani, M. (2011). The Arab ‘youth quake’: Implications on democratization and stability. Middle East Law and Governance, 3, 159-170.

Al Qasimi, B. (2011). Digital publishing and its impact on the publishing industry in the Arab world.Publishing Research Quarterly, 27(4), 338-344.

Alqudsi-ghabra, T. (2012). Creative use of social media in the revolutions of Tunisia, Egypt \& Libya.The International Journal of Interdisciplinary Social Sciences, 6(6), 147-158.

Al-Rafee, S., \&Rouibah, K. (2010). The fight against digital piracy: An experiment. Telematics and Informatics, 27(3), 283-292.

Al-Saggaf, Y. (2006). The online public sphere in the Arab world: The war in Iraq on the Al Arabiya website. Journal of Computer-Mediated Communication, 12, 311-334.

Aouragh, M. (2008). Everyday resistance on the Internet: The Palestinian context. Journal of Arab \& Muslim Media Research, 1(2), 109-130.

Ayyad, K. (2011). Internet usage vs. traditional media usage among university students in the United Arab Emirates.Journal of Arab \& Muslim Media Research, 4(1): 41-61.

Barker, V., \& Ota, H. (2011).Mixi diary versus Facebook photos: Social networking site use among Japanese and Caucasian American females. Journal of Intercultural Communication Research, 40(1), 39-63.

Barry, W., \&Bouvier, G. (2011). Cross-cultural communication: Arab and Welsh students’ use of Facebook. Journal of Arab \& Muslim Media Research, 4(2-3), 165-184.

Campbell, S. W. (2007a). A cross-cultural comparison of perceptions and uses of mobile telephony.New Media \& Society, 9(2), 343-363. 
Campbell, S. W. (2007b). Perceptions of mobile phone use in public settings: A crosscultural comparison. International Journal of Communication, 1, 738-757.

Central Intelligence Agency. (2012). The world factbook. Accessed December 3, 2012, at https://www.cia.gov/library/publications/the-worldfactbook/rankorder/2119rank.html.

Chen, G. (2012). The impact of new media on intercultural communication in global context.China Media Research 8(2), 1-10.

Daoudi, A. (2011). Globalisation and e-Arabic: The emergence of a new language at the literal and figurative levels. In C. Hasselblatt, P. Houtzagers, \& R. van Pareren (Eds.), Language Contact in Times of Globalization (pp. 61-76). Amsterdam: Rodopi.

El-Baltaji, D. (2009). Emirates press law. Arab Media \& Society, 9.Accessed Nov. 25, 2012, at http://www.arabmediasociety.com/?article=727

Elsadda, H. (2010). Arab women bloggers: The emergence of literary counterpublics. Middle East Journal of Culture and Communication, 3, 312-332.

Eltantawy, N., \&Wiest, J. B. (2011). Social media use in the Egyptian revolution: Reconsidering resource mobilization theory. International Journal of Communication, 5, 1207-1224.

Ghannam, J. (2011). Social media in the Arab world: Leading up to the uprisings of 2011. Center for International Media Assistance. Accessed May 9, 2012, at http://cima.ned.org/ publications/social-media-arab-world-leading-uprisings-2011-0

Haggan, M. (2007). Text messaging in Kuwait: Is the medium the message? Multilingua, 26, 427-449.

Harp, D., Bachmann, I., \&Guo, L. (2012). The whole online world is watching: Profiling social networking sites and activists in Chine, Latin America, and the United States. International Journal of Communication, 6, 298-321.

Hjarvard, S. (2008). The mediatization of society: A theory of the media as agents of social and cultural change. Nordicom Review, 29(2), 105-134.

Human Rights Watch. (2011). World report 2011: United Arab Emirates. Accessed May 9, 2012, at http://www.hrw.org/world-report-2011/united-arab-emirates

Iskander, E. (2011). Connecting the national and the virtual: Can social media have a role in institution-building after Egypt's January 25 uprising? International Journal of Communication, 5, 1225-1237. 
Lenhart, A. (2012). Teens, smartphones \& texting.Pew Internet \& American Life Project. Accessed October 20, 2012, at http://www.pewinternet.org/ /media//Files/Reports/2012/ PIP_Teens_Smartphones_and_Texting.pdf

Lenhart, A., Purcell, K., Smith, A., \&Zickuhr, K. (2010).Social media \& mobile Internet use among teens and young adults.Pew Internet \& American Life Project. Accessed October 20, 2012, at http://www.pewinternet.org/ /media//Files/Reports/2010/PIP_Social_ Media_and_Young_Adults_Report_Final_with_toplines.pdf

Leonardi, P. M. (2003). Problematizing “new media”: Culturally based perceptions of cell phones, computers, and the Internet among United States Latinos. Critical Studies in Media Communication, 20(2), 160-179.

Lin, A. M. Y., \& Tong, A. H. M. (2007). Text-messaging cultures of college girls in Hong Kong: SMS as resources for achieving intimacy and gift-exchange with multiple functions. Continuum: Journal of Media \& Cultural Studies, 21(2), 303-315.

Mertens, S., \&d'Haenens, L. (2010). The digital divide among young people in Brussels: Social and cultural influences on ownership and use of digital technologies. Communications, 35, 187-207.

Mohamed, A. S. (2011). On the road to democracy: Egyptian bloggers and the Internet 2010. Journal of Arab \& Muslim Media Research, 4(2-3), 253-272.

Monteiro, B. (2008). Blogs and female expression in the Middle East.Media Development, 3, 47-53.

Moosa, K. (2002). National nutrition survey for adult Bahrainis aged 19 years and above. Kingdom of Bahrain Ministry of Health Nutrition Section.Accessed June 26, 2012, at http://www.moh.gov.bh/pdf/survey/nut_survey1.pdf

Mourtada, R., \& Salem, F. (2011). Civil movements: The impact of Facebook and Twitter. Arab Social Media Report, 1(2): 1-30.

Muhtaseb, A., \& Frey, L. R. (2008).Arab Americans’ motives for using the Internet as a functional media alternative and their perceptions of U.S. public opinion.Journal of Computer Mediated Communication, 13, 618-657.

Ng, S. W., Zaghloul, S., Ali, H., Harrison, G., Yeatts, K., El Sadig, M., \&Popkin, B. M. (2011).Nutrition transition in the United Arab Emirates.European Journal of Clinical Nutrition, 65(12): 1328-1337. 
Pew Research Center. (2011). Global digital communication: Texting, social networking popular worldwide. Pew Global Attitudes Project. Accessed June 26, 2012, at http://www.pewglobal.org/files/2011/12/Pew-Global-Attitudes-Technology-ReportFINAL-December-20-20111.pdf

Rainie, L. (2012). Changes to the way we identify Internet users. Pew Internet \& American Life Project. Accessed November 7, 2012, at http://pewinternet.org/ /media//Files/Reports/ 2012/Commentary\%20-\%20counting\%20internet\%20users.pdf

Rainie, L., Smith, A., Schlozman, K. L., Brady, H., \&Verba, S. (2012). Social media and political engagement.Pew Internet \& American Life Project. Accessed November 7, 2012, at http://pewinternet.org/ /media//Files/Reports/2012/PIP_SocialMediaAnd PoliticalEngagement_PDF.pdf

Russell, A. (2011). Extra-national information flows: Social media and the 2011 Egyptian uprising. International Journal of Communication, 5, 1238-1247.

Salem, F., \&Mourtada, R. (2012). Social media in the Arab world: Influencing societal and cultural change? Arab Social Media Report, 2(1). Accessed October 30, 2012, at http://www.arabsocialmediareport.com/UserManagement/PDF/ASMR\%204\%20upda ted\%2029\%2008\%2012.pdf

Schulz, W. (2004).Reconstructing mediatization as an analytical concept.European Journal of Communication, 19(1), 87-101.

Shuter, R., \&Chattopadhyay, S. (2010). Emerging interpersonal norms of text messaging in India and the United States.Journal of Intercultural Communication Research, 39(2), 123-147.

Singh, C. L. (2010). New media and cultural identity.China Media Research, 6(1), 86-90.

Smith, A. (2011). Why Americans use social media. Pew Internet \& American Life Project. Accessed October 20, 2012, at http://www.pewinternet.org/ /media//Files/Reports/2011/ Why\%20Americans\%20Use\%20Social\%20Media.pdf

Smith, A., \& Brenner, J. (2012). Twitter use 2012. Pew Internet \& American Life Project. Accessed October 20, 2012, at http://www.pewinternet.org/ /media//Files/Reports/2012/ PIP_Twitter_Use_2012.pdf 
Sokol, D., \&Sisler, V. (2010).Socializing on the Internet: Case study of Internet use among university students in the United Arab Emirates.Global Media Journal, 9(16), 1-34.

Sreekumar, T. T. (2011). Mobile phones and the cultural ecology of fishing in Kerala, India.The Information Society, 27, 172-180.

Telhami, S. (2003). A view from the Arab world: A survey in five countries. The Brookings Institution. Accessed June 26, 2012, at http://www.brookings.edu/ /media/research/ files/reports/2003/3/middleeast\%20telhami/survey20030313.pdf

Thompson, J. B. (1995). The media and modernity: A social theory of the media. Cambridge: Polity Press.

U.S. Department of State (2011). Background note: United Arab Emirates. Accessed June 26, 2012, at http://www.state.gov/r/pa/ei/bgn/5444.htm

Vasalou, A., Joinson, A. N., \& Courvoisier, D. (2009).International Journal of HumanComputer Studies, 68, 719-728.

Wall, M., \& El Zahed, S. (2011). “I’ll be waiting for you guys”: A YouTube call to action in the Egyptian revolution. International Journal of Communication, 5, 1333-1343.

Wasserman, H. (2011). Mobile phones, popular media, and everyday African democracy: Transmissions and transgressions. Popular Communication, 9, 146-158.

Weber, R. H. (2011). Politics through social networks and politics by government blocking: Do we need new rules? International Journal of Communication, 5, 1186-1194.

Wiest, J. B., \&Eltantawy, N. (2012). Social media use among UAE college students one year after the Arab Spring. Journal of Arab \& Muslim Media Research. Manuscript submitted for publication.

World Bank.(2011). Internet users. Accessed November 7, 2012, at http://data.worldbank.org/indicator/IT.NET.USER/countries

Zickuhr, K., \& Smith, A. (2012).Digital differences.Pew Internet \& American Life Project. Accessed November 7, 2012, at http://pewinternet.org/ /media//Files/Reports/2012/ PIP_Digital_differences_041312.pdf 
Table 1. Test results

$\begin{array}{ll}\text { Testing hypotheses } & \text { Test }\end{array}$

Test

statistic

RQ1: Is there a relationship between online and cellular device ownership and nationality?

\begin{tabular}{|c|c|c|}
\hline $\begin{array}{l}\text { H1a: There is a relationship between owning a cell } \\
\text { phone AND nationality. }\end{array}$ & Chi-square & $37.592 * *$ \\
\hline $\begin{array}{l}\text { H1b: There is a relationship between owning a personal } \\
\text { computer AND nationality. }\end{array}$ & Chi-square & $77.595 * *$ \\
\hline $\begin{array}{l}\text { H1c: There is a relationship between owning a game } \\
\text { console AND nationality. }\end{array}$ & Chi-square & $54.927 * *$ \\
\hline $\begin{array}{l}\text { H1d: There is a relationship between owning a portable } \\
\text { gaming device AND nationality. }\end{array}$ & Chi-square & $15.949 * *$ \\
\hline $\begin{array}{l}\text { H1e: There is a relationship between owning an iPod or } \\
\text { MP3 player AND nationality. }\end{array}$ & Chi-square & 2.803 \\
\hline
\end{tabular}

RQ2: Is there a relationship between online and cellular activities and nationality?

H2a: There is a relationship between using the Internet

AND nationality.

Chi-square $\quad 13.041^{* *}$

H2b: There is a relationship between using email AND nationality.

Chi-square

H2c: There is a relationship between use of social networking services AND nationality.

Chi-square

$14.729 * *$

H2d: There is a relationship between use of Twitter

AND nationality.

Chi-square

$333.225^{* *}$

H2e: There is a relationship between visiting virtual worlds AND nationality.

Chi-square $9.397 * *$

H2f: There is a relationship between creating or working on an online journal or blog AND nationality.

Chi-square

$58.123^{* *}$

H2g: There is a relationship between remixing online material into an original work AND nationality.

Chi-square 77.295**

H2h: There is a relationship between online purchasing Chi-square

1.127 
AND nationality.

H2i: There is a relationship between sharing an original work online AND nationality.

Chi-square

$46.349^{* *}$

$\mathrm{H} 2 \mathrm{j}$ : There is a relationship between searching online for uncomfortable health information AND nationality.

H2k: There is a relationship between searching online

for health, dieting, or fitness information AND Chi-square

$135.243^{* *}$

nationality.

H2l: There is a relationship between searching online

for information about current events or politics AND Chi-square nationality.

\begin{tabular}{|c|c|c|}
\hline $\begin{array}{l}\text { H2m: There is a relationship between Internet use on a } \\
\text { personal computer AND nationality. }\end{array}$ & Chi-square & $9.232 * *$ \\
\hline $\begin{array}{l}\text { H2n: There is a relationship between Internet use on a } \\
\text { personal game console AND nationality. }\end{array}$ & Chi-square & $5.351^{*}$ \\
\hline $\begin{array}{l}\text { H2o: There is a relationship between Internet use on a } \\
\text { personal portable gaming device AND nationality. }\end{array}$ & Chi-square & $17.995^{* *}$ \\
\hline $\begin{array}{l}\text { H2p: There is a relationship between Internet use on a } \\
\text { personal cell phone AND nationality. }\end{array}$ & Chi-square & $240.038 * *$ \\
\hline
\end{tabular}




\section{RQ3: Does the frequency of online and cellular}

\section{activities vary by nationality?}

\begin{tabular}{|c|c|c|}
\hline \multirow[t]{2}{*}{ H3a: Frequency of Internet use varies by nationality. } & \multicolumn{2}{|l|}{ Mann-Whitney } \\
\hline & $\begin{array}{l}\text { (grouped by } \\
\text { nationality) }\end{array}$ & $26581.000 * *$ \\
\hline $\begin{array}{l}\text { H3b: Frequency of cell phone use to browse or update } \\
\text { social networking profiles varies by nationality. }\end{array}$ & $\begin{array}{l}\text { Mann-Whitney } \\
\text { (grouped by } \\
\text { nationality) }\end{array}$ & 48339.000 \\
\hline $\begin{array}{l}\text { H3c: Frequency of posting comments to a friend's blog } \\
\text { varies by nationality. }\end{array}$ & $\begin{array}{l}\text { Mann-Whitney } \\
\text { (grouped by } \\
\text { nationality) }\end{array}$ & $163557.000^{* *}$ \\
\hline $\begin{array}{l}\text { H3d: Frequency of adding comments to a friend's } \\
\text { picture varies by nationality. }\end{array}$ & $\begin{array}{l}\text { Mann-Whitney } \\
\text { (grouped by } \\
\text { nationality) }\end{array}$ & $163440.000^{* *}$ \\
\hline $\begin{array}{l}\text { H3e: Frequency of posting comments to a friend's page } \\
\text { or wall varies by nationality. }\end{array}$ & $\begin{array}{l}\text { Mann-Whitney } \\
\text { (grouped by } \\
\text { nationality) }\end{array}$ & $166039.000^{* *}$ \\
\hline $\begin{array}{l}\text { H3f: Frequency of joining groups on a social } \\
\text { networking service varies by nationality. }\end{array}$ & $\begin{array}{l}\text { Mann-Whitney } \\
\text { (grouped by } \\
\text { nationality) }\end{array}$ & $169683.000^{* *}$ \\
\hline $\begin{array}{l}\text { H3g: Frequency of sending a bulletin or group message } \\
\text { to a group of friends varies by nationality. }\end{array}$ & $\begin{array}{l}\text { Mann-Whitney } \\
\text { (grouped by } \\
\text { nationality) }\end{array}$ & $167670.000^{* *}$ \\
\hline $\begin{array}{l}\text { H3h: Frequency of sending instant messages or text } \\
\text { messages to a friend through social networking } \\
\text { services varies by nationality. }\end{array}$ & $\begin{array}{l}\text { Mann-Whitney } \\
\text { (grouped by } \\
\text { nationality) }\end{array}$ & $180542.500^{* *}$ \\
\hline $\begin{array}{l}\text { H3i: Frequency of sending private messages to a friend } \\
\text { within social networking services varies by nationality. }\end{array}$ & $\begin{array}{l}\text { Mann-Whitney } \\
\text { (grouped by } \\
\text { nationality) }\end{array}$ & $169027.000^{* *}$ \\
\hline Significant at the 0.05 level (2-tailed) & & \\
\hline ** Significant at the 0.01 level (2-tailed) & & \\
\hline
\end{tabular}

